\title{
GAMBARAN HIGIENE SANITASI PENGELOLAAN MAKANAN DI RUMAH SAKIT ABC KABUPATEN KUBU RAYA KALIMANTAN BARAT
}

\author{
Faradila Sintia, Susilawati, Fathmawati \\ (Jursan Kesehatan Lingkungan Politeknik Kesehatan Kemenkes Pontianak)
}

\begin{abstract}
Hospital is a health service institution that conducts complete individual health services, which include inpatient, outpatient, and emergency services. Hospitals should minimize the source of diseases caused by food, especially for patients who are hospitalized, therefore hospitals must meet the hygiene requirements for food management. This study aims to describe the implementation of food management sanitation hygiene at ABC Hospital Kubu Raya Regency. This was a descriptive study by observing the components of food management sanitation hygiene at ABC Hospital. Data were collected using a checklist. The analysis was done by comparing the results obtained with the assessment component based on the some Minister of Health regulations. The results of this study indicate that some components of food management must be improved in order to ensure the safety and health of users. Further research needs to develop an instrument for assessing foodmanagement sanitation hygiene in a hospital
\end{abstract}

Keywords: Hygiene; Sanitation; Food-Management; Hospital

\begin{abstract}
Abstrak
Rumah sakit merupakan institusi pelayanan kesehatan yang menyelenggarakan pelayanan kesehatan lengkap meliputi rawat pelayanan inap, rawat jalan, dan gawat darurat. Rumah sakit harus meminimalkan sumber penyakit yang disebabkan oleh makanan, khususnya bagi pasien yang dirawat. Oleh karena itu rumah sakit harus memenuhi persyaratan higiene penegelolaan makanan. Penelitian ini bertujuan untuk mendeskripsikan pelaksanaan higiene sanitasi pengelolaan makanan di Rumah Sakit ABC Kabupaten Kubu Raya. Penelitian ini merupakan penelitian deskriptif yang mengamati komponen higiene sanitasi pengelolaan makanan di Rumah Sakit ABC. Data dikumpulkan menggunakan ceklis. Analisis dilakukan dengan membandingkan hasil pengamatan dari komponen penilaian dengan beberapa Peraturan Menteri Kesehatan. Hasil menunjukkan bahwa beberapa komponen dalam pengelolaan makanan harus diperbaiki untuk menjamin keamanan dan Kesehatan pengguna. Perlu dilakukan penelitian lanjutan untuk mengembangkan instrumen penilaian higiene sanitasi pengelolaan makanan di rumah sakit.
\end{abstract}

Keywords: Higiene; Sanitasi; Pengelolaan Makanan; Rumah Sakit

\section{PENDAHULUAN}

Manusia memerlukan makanan untuk kelangsungan hidupnya untuk mendapatkan tenaga dan nutrisi. Di sisi lain, makanan dapat menjadi penyebab atau sumber penyakit jika proses pengolahannya tidak memperhatikan prinsip higiene sanitasi makanan ${ }^{1}$. Sanitasi makanan adalah salah satu upaya pencegahan yang mengutamakan pada kegiatan dan tindakan yang diperlukan. Hal ini untuk memastikan bahwa makanan dan minuman bebas dari segala bahaya yang dapat mengganggu atau merusak kesehatan mulai dari sebelum makanan diproduksi, selama proses pengolahan, penyiapan, pengangkutan, penyajian sampai pada saat makanan dan minuman tersebut siap untuk didistribusikan kepada 
konsumen. Upaya pengendalian elemen makanan, orang, tempat dan perlengkapannya yang dapat atau mungkin dapat megakibatkan penyakit atau ancaman kesehatan merupakan prinsip higiene sanitasi makanan.

Beberapa pathogen utama yang masuk ke dalam tubuh melalui makanan yang terkontaminasi dapat menyebabkan penyakit yang disebut penyakit bawaan makanan (food borne disease). Patogen utama tersebut meliputi Salmonella sp, Staphylococcus aureus, Escherichia coli, Candida albicans, Bacillus spp, Bacillus subtilis. Patogen-patogen ini mengontaminasi makanan melalui antara lain kebiasaan mengolah makanan secara tradisional, penyimpanan dan penyajian yang tidak bersih dan tidak memenuhi persyaratan sanitasi. Diperkirakan sekitar $70 \%$ kasus diare yang terjadi di negara berkembang disebabkan oleh makanan yang telah terkontaminasi ${ }^{2}$. Kasus keracunan makanan yang terjadi di Indonesia pada periode Januari hingga September 2014 tercatat 97 insiden keracunan makanan, 49 kasus yang terjadi disebabkan oleh pengolahan jasa boga, dengan korban yang tercatat sebanyak 1.944 orang yang sakit dan 1 orang meninggal dunia ${ }^{3}$.

Pasien yang sedang dalam perawatan dan masa penyembuhan di rumah sakit memerlukan makanan yang aman agar tidak menimbulkan masalah baru dan membebani tubuhnya dengan kontaminan baru. Begitu juga halnya dengan petugas rumah sakit yang memerlukan makanan yang aman agar dapat memberikan pelayanan dengan baik. Penyelenggaraan makanan untuk pasien dan petugas di Rumah Sakit ABC Kubu Raya dikelola sendiri oleh rumah sakit di dapur gizi sejak 2016. Sebelumnya, pengelolaan makanan diserahkan kepada pihak ke-tiga.

Hasil observasi awal di rumah sakit ABC menunjukkan kereta dorong yang digunakan untuk mendistribusikan makanan dalam keadaan tidak utuh. Pintu kereta sudah tidak lengkap (rusak) sehingga memungkinkan makanan terkontaminasi sepanjang perjalanan. Selain itu ditemukan, peralatan memasak yang sudah tidak lengkap seperti gagang wajan yang lepas sehingga menyulitkan petugas saat mengolah makanan. Penelitian ini bertujuan untuk mendeskripsikan higiene sanitasi pengelolaan makanan di Rumah sakit $A B C$ Kabupaten Kubu Raya.

\section{METODE PENELITIAN}

Jenis penelitian yang digunakan adalah deskriptif. Penelitian dilakukan mulai pada Januari-Mei 2019. Peneliti mengamati penerapan enam prinsip pengelolaan makanan, meliputi pemilahan bahan makanan, penyimpanan bahan makanan mentah dan matang, pengolahan makanan, transportasi makanan, penyajian makanan dan penjamah makanan di Rumah sakit ABC menggunakan cheklist sebagai alat ukur. Checklist dibuat berdasarkan Permenkes No. 7 tahun 2019 tentang Persyaratan Kesehatan Lingkungan Rumah Sakit, Permenkes No. 1096 tahun 2011 tentang Hygiene Sanitasi Jasa Boga, Permenkes No. 78 
tentang Pedoman Pelayanan Gizi Rumah Sakit dan Permenkes No. 56 tahun 2014 tentang Klasifikasi Rumah Sakit ${ }^{4-7}$ serta berdasarkan masukan dari orang yang dianggap ahli dalam pengelolaan sanitasi makanan.

Checklist terdiri atas tujuh bagian sesuai prinsip pengelolaan makanan. Setiap prinsip diberi bobot berdasarkan risiko yang dapat ditimbulkannya. Masing-masing prinsip memiliki komponen penilaian. Pemilahan bahan makanan terdiri atas penilaian kondisi bahan makanan secara fisik, penggunaan bahan tambahan pangan (BTP), kondisi bahan makanan kemasan, dan tempat pembelian bahan makanan. Penyimpanan bahan makanan terdiri atas penilaian tempat penyimpanan bahan makanan yang mudah membusuk, kebersihan, bebas gangguan serangga dan tikus, serta penyimpanan bahan makanan dan minuman. Pengolahan makanan terdiri atas penilaian persyaratan teknis dapur, kebersihan lantai dapur, kondisi peralatan memasak, cara pencucian peralatan memasak, wadah makanan, serta kelengkapan cerobong asap.

Penyimpanan makanan jadi terdiri atas penilaian penyimpanan, kualitas makanan, serta wadah makanan. Pengangkutan makanan terdiri atas penilaian terhadap kualifikasi kereta (troli), penggunaan troli, serta jalur pengangkutan. Penyajian makanan terdiri atas penilaian terhadap risiko pencemaran, wadah untuk penyajian makanan, kualitas makanan, serta suhu makanan. Terakhir adalah penjamah makanan yang terdiri atas penilaian terhadap kepemilikan surat keerangan sehat, tidak berkuku panjang/berpenyakit kulit, penggunaan alat pelindung diri (APD), dan perilaku hidup bersih. Setiap prinsip pengelolaan makanan memiliki nilai maksimal 100 yang terbagi dalam setiap komponen penilaian. Nilai setiap komponen berbeda tergantung risiko bahaya yang ditimbulkan. Pemberian skor dilakukan sesuai hasil pengamatan. Penyajian data diolah dalam bentuk deskriptif yaitu penjabaran dalam bentuk tabel yang dilengkapi dengan narasi.

\section{HASIL PENELITIAN}

Rumah Sakit ABC yang terletak di ibukota Kabupaten Kubu Raya Provinsi Kalimantan Barat merupakan rumah sakit tipe C. Rumah sakit ini memiliki luas tanah $31.798 \mathrm{~m}^{2}$ dan luas bangunan $5.061 \mathrm{~m}^{2}$ dengan kapasitas jumlah tempat tidur sebanyak 135 buah dan jumlah tenaga kesehatan sebanyak 213 orang. Petugas yang mengelola makanan di rumah sakit ini sebanyak 16 orang dan dua orang nutrisionis. Mereka bekerja secara bergiliran (shift) yaitu pagi dan sore. Pelayanan makanan diberikan sebanyak tiga kali dalam sehari.

Rumah sakit ini ditetapkan menjadi Fasilitas Kesehatan Tingkat Lanjut (FKTL) yang mengubah sistem pelayanan menjadi pelayanan rujukan berjenjang pada 2014 berdasarkan UU RI No. 11 tahun 2011 tentang Badan Penyelenggaraan Jaminan Sosial (BPJS). Komisi Akreditasi Rumah Sakit (KARS) juga telah menetapkan Rumah Sakit ABC terakreditasi paripurna pada 2018. Fasilitas pendukung di rumah sakit ini diantaranya adalah Unit Gawat 
Darurat (UGD), Ruang Bedah, Ruang Jenazah, Instalasi Rawat Inap, Instalasi Rawat Jalan, Instalasi Pendidikan, Instalasi Gizi, dan Instalasi Pemeliharaan Sarana Rumah Sakit. Secara keseluruhan, dapat dikatakan bahwa pengelolaan makanan di Rumah Sakit ABC sudah menerapkan hampir keseluruhan komponen higiene sanitasi pengelolaan makanan di rumah sakit. Hasil pengamatan dapat dilihat pada Tabel 1.

Tabel 1. Penilaian Higiene Sanitasi Pengelolaan Makanan

\begin{tabular}{|c|c|c|c|}
\hline Komponen & Bobot & Nilai & Skor \\
\hline Pemilahan bahan makanan & 2 & & \\
\hline $\begin{array}{l}\text { Kondisi bahan makanan mentah (segar) secara fisik } \\
\text { memenuhi syarat yaitu dalam keadaan baik, segar dan } \\
\text { tidak rusak atau berubah bentuk, warna dan rasa, serta } \\
\text { sebaiknya berasal dari tempat resmi yang diawasi dan } \\
\text { tanggal kadaluwarsa harus jelas. }\end{array}$ & & 40 & 80 \\
\hline $\begin{array}{l}\text { Bahan Tambahan Pangan (BTP) yang dipakai harus } \\
\text { memenuhi persyaratan sesuai peraturan yang berlaku }\end{array}$ & & 20 & 40 \\
\hline $\begin{array}{l}\text { seperti zat pewarna,pengawet dan zat pemanis buatan. } \\
\text { Bahan makanan kemasan (terolah) harus mempunyai label } \\
\text { dan merek serta dalam dalam keadaan baik }\end{array}$ & & 20 & 40 \\
\hline $\begin{array}{l}\text { Pembelian bahan sebaiknya ditempat yang resmi dan } \\
\text { berkualitas baik. }\end{array}$ & & 20 & 40 \\
\hline Sub Total & & & 200 \\
\hline Penyimpanan bahan makanan & 3 & & \\
\hline $\begin{array}{l}\text { Makanan yang mudah membusuk disimpan pada suhu } \\
0^{\circ} \mathrm{C}-4^{\circ} \mathrm{C}\end{array}$ & & 30 & 90 \\
\hline Bersih, Terlindung dari debu & & 30 & 90 \\
\hline Bebas gangguan serangga dan tikus & & 20 & 45 \\
\hline Bahan makanan dan minuman terpisah & & 20 & 60 \\
\hline Sub Total & & & 285 \\
\hline Pengolahan makanan & 4 & & \\
\hline $\begin{array}{l}\text { Tempat pengolahan makanan atau dapur harus memenuhi } \\
\text { persyaratan teknis higiene sanitasi untuk mencegah risiko } \\
\text { pencemaran terhadap makanan dan dapat mencegah } \\
\text { masuknya vektor }\end{array}$ & & 20 & 80 \\
\hline $\begin{array}{l}\text { Lantai dapur sebelum dan sesudah kegiatan dibersihkan } \\
\text { dengan antiseptic }\end{array}$ & & 20 & 80 \\
\hline $\begin{array}{l}\text { Peralatan masak dan peralatan makan terbuat dari bahan } \\
\text { tara pangan (food grade) yang aman, tahan karat, tidak } \\
\text { mengandung bahan beracun, utuh, tidak retak dan tidak } \\
\text { berbahaya bagi kesehatan }\end{array}$ & & 20 & 40 \\
\hline $\begin{array}{l}\text { Dicuci dengan desinfektan atau dikeringkan dengan sinar } \\
\text { matahari/pemanas buatan dan tidak dibersihkan dengan } \\
\text { kain }\end{array}$ & & 20 & 80 \\
\hline $\begin{array}{l}\text { Wadah yang digunakan harus mempunyai tutup yang } \\
\text { dapat menutup sempurna dan dapat mengeluarkan udara } \\
\text { panas }\end{array}$ & & 10 & 40 \\
\hline Dilengkapi dengan sungkup dan cerobong asap & & 10 & 40 \\
\hline Sub Total & & & 360 \\
\hline Penyimpanan makanan jadi & 3 & & \\
\hline $\begin{array}{l}\text { Makanan yang akan disajikan }>6 \text { jam disimpan pada suhu } \\
-5^{\circ} \mathrm{C} \text { s.d. }-1^{\circ} \mathrm{C}\end{array}$ & & 40 & 120 \\
\hline
\end{tabular}




\begin{tabular}{|c|c|c|c|}
\hline Komponen & Bobot & Nilai & Skor \\
\hline $\begin{array}{l}\text { Makanan tidak rusak, tidak busuk atau basi yang ditandai } \\
\text { dari rasa, bau, berlendir, berubah warna, berjamur, } \\
\text { berubah aroma atau adanya cemaran lain }\end{array}$ & & 30 & 90 \\
\hline $\begin{array}{l}\text { Tempat atau wadah penyimpanan terpisah sesuai jenis } \\
\text { makanan jadi dan mempunyai tutup yang menutup } \\
\text { sempurna tetapi berventilasi yang dapat mengeluarkan } \\
\text { uap air. }\end{array}$ & & 30 & 75 \\
\hline Sub Total & & & 285 \\
\hline Pengangkutan makanan & 2 & & \\
\hline Menggunakan kereta dorong tertutup & & 40 & 40 \\
\hline $\begin{array}{l}\text { Pengisian kereta dorong tidak sampai penuh,agar tersedia } \\
\text { udara untuk ruang gerak }\end{array}$ & & 40 & 80 \\
\hline $\begin{array}{l}\text { Lalu lintas makanan jadi menggunakan jalur khusus yang } \\
\text { terpisah dengan jalur untuk mengangkut bahan atau } \\
\text { barang kotor. }\end{array}$ & & 20 & 40 \\
\hline Sub Total & & & 160 \\
\hline Penyajian makanan & 2 & & \\
\hline $\begin{array}{l}\text { Penyajian makanan terhindar dari pencemaran dan } \\
\text { peralatan yang dipakai harus bersih }\end{array}$ & & 30 & 50 \\
\hline $\begin{array}{l}\text { Makanan jadi yang siap disajikan harus diwadahi dan } \\
\text { tertutup }\end{array}$ & & 30 & 60 \\
\hline Tidak menyajikan makanan yang menginap & & 20 & 40 \\
\hline $\begin{array}{l}\text { Makanan di sajikan dalam keadaan hangat dengan suhu } \\
60^{\circ} \mathrm{C} \text { dan } 4^{\circ} \mathrm{C} \text { untuk makanan dingin. }\end{array}$ & & 20 & 40 \\
\hline Sub Total & & & 190 \\
\hline Penjamah Makanan & 2 & & \\
\hline Memiliki surat keterangan sehat yang berlaku & & 30 & 60 \\
\hline Tidak berkuku panjang, koreng dan sejenisnya & & 20 & 40 \\
\hline Menggunakan pakaian pelindung pengolahan makanan & & 20 & 40 \\
\hline $\begin{array}{l}\text { Selalu menggunakan peralatan dalam menjamah makanan } \\
\text { jadi }\end{array}$ & & 20 & 20 \\
\hline $\begin{array}{l}\text { Berprilaku bersih dan sehat selama bekerja, seperti } \\
\text { mencuci tangan dengan sabun sebelum mengolah } \\
\text { makanan, dan lainnya. }\end{array}$ & & 10 & 20 \\
\hline Sub Total & & & 180 \\
\hline
\end{tabular}

Tabel 1 menunjukkan bahwa sebagian besar komponen penilaian memiliki nilai penuh, kecuali pada komponen bebas gangguan serangga dan tikus, peralatan memasak yang digunakan, wadah penyimpanan bahan makanan jadi, penggunaan kereta dorong, penyajian makanan, dan perilaku penjamah makanan dalam menggunakan peralatan dalam menjamah makanan. Perangkap lalat tidak ditemukan pada saat observasi. Petugas masih menggunakan peralatan memasak yang sudah rusak kondisinya seperti lapisan permukaan wajan dan fry pan yang sudah terlepas, serta pegangan yang rusak.

Beberapa jenis masakan yang sudah jadi ditemukan tidak dipindahkan ke wadah khusus makanan jadi. Makanan ini tetap dalam wadah pengolahan (panci atau wajan) untuk kemudian langsung ditempatkan pada wadah makanan yang akan disajikan kepada pasien. Kereta dorong yang digunakan untuk mendistribusikan makanan dalam keadaan tidak utuh. 
Pintu kereta makanan sudah rusak (terlepas) sehingga wadah makanan dapat langsung kontak degan udara. Pada saat menjamah makanan jadi, petugas terkadang tidak menggunakan peralatan walaupun tetap mengenakan sarung tangan.

\section{PEMBAHASAN}

Meskipun secara umum pengelolaan makanan di Rumah Sakit ABC dikategorikan sudah memenuhi komponen higiene sanitasi pengelolaan makanan, namun ada beberapa hal yang perlu mendapat perhatian atau perbaikan. Sementara yang hal-hal yang sudah baik perlu dipertahankan dan ditingkatkan. Komponen penilaian bebas gangguan serangga dan tikus sudah dilaksanakan oleh rumah sakit. Bahan makanan disimpan dalam rak yang disusun sedemikian rupa sehingga tidak memungkinkan tikus bersarang. Keberadaan tikus di rumah sakit sangat berhubungan dengan kebersihan ${ }^{8}$. Sampah yang dihasilkan harus selalu diangkut dan dibuang keluar lokasi rumah sakit. Penelitian ini tidak menyertakan pengelolaan sampah dalam komponen pengamatan, tetapi pada saat penelitian dilakukan tampak bahwa lingkungan rumah sakit terjaga kebersihannya. Hal ini harus ditingkatkan dengan selalu melakukan pengawasan kebersihan rumah sakit oleh petugas sanitasi.

Meskipun pada saat pengamatan dilakukan tidak ditemukan gangguan insekta seperti lalat dan kecoa, rumah sakit perlu menyiapkan perangkap lalat. Beberapa penelitian menunjukkan bahwa perangkap lalat eletrik dapat digunakan untuk mengendalikan lalat rumah ${ }^{9,10}$. Penggunaan insektisida untuk pengendalian lalat sebaiknya dihindari karena selain membahayakan (terjadi pencemaran makanan). Sebuah penelitian di Indonesia melaporkan lalat sudah resisten terrhadap beberapa jenis insektisida ${ }^{11}$. Penelitian ini mendapatkan bahwa ruang pengolahan makanan selalu terjaga kebersihannya. Hal ini menyebabkan tidak ditemukan gangguan serangga dan tikus di instalasi ini. Tempat pengolahan makanan mempunyai peranan penting dalam proses pengolahan makanan agar tidak terjadi kontaminasi silang antara tempat pengolahan dan makanan olahan, karena itu kebersihan tempat pengolahan dan lingkungan sekitarnya harus selalu terjaga dan diperhatikan ${ }^{12}$.

Peralatan memasak yang sudah rusak kondisinya sebaiknya diganti dengan yang baru. Hasil pengamatan menunjukkan bahwa ada peralatan memasak seperti wajan dan fry pan lapisan terluarnya sudah terlepas. Partikel-partikel logam yang terdapat pada peralatan memasak seperti wajan dan fry pan dapat terlepas ataupun larut ke dalam makanan yang sedang diolah sehingga berbahaya bagi kesehatan. Hal ini sangat perlu diperhatikan karena dapat menyebabkan keracunan logam berat pada manusia, khususnya pasien yang kondisinya dalam keadaan lemah dan rentan terkena penyakit ${ }^{13}$. Selain itu, peralatan memasak yang tidak utuh lagi kondisinya harus diganti karena dapat membahayakan keselamatan petugas karena risiko kecelakaan terkena tumpahan minyak panas atau 
makanan panas. Selain pasien, keselamatan dan keamanan petugas (penjamah makanan) rumah sakit juga harus dilindungi ${ }^{14,15}$.

Makanan yang sudah selesai diproses sebaiknya dipindahkan ke wadah khusus makanan yang sudah jadi sebelum ditata pada wadah makanan pasien/petugas. Hal ini untuk melindungi petugas pengolah makanan dari risiko kecelakaan. Penggunaan alat memasak sebagai wadah makanan berpotensi menimbulkan kecelakaan karena bentuknya yang tidak memungkinkan dalam kondisi stabil. Wajan merupakan salah satu contoh yang tidak stabil jika diletakkan pada tempat yang datar karena bentuknya yang cembung pada bagian bawah. Penggunan troli masih belum sesuai yang disyaratkan oleh Permenkes no. 56 tahun 2014. Troli yang digunakan oleh rumah sakit sudah tidak memiliki pintu. Pintu berfungsi untuk melindungi makanan terkontaminasi dari lingkungan sekitarnya serta potensi kecelakaan. Walaupun makanan yang dibawa dalam keadaan tertutup, tetapi masih membahayakan pasien karena wadah makanan langsung kontak dengan udara luar 16 . Sebaiknya manajemen rumah sakit segera menggganti troli yang sudah tidak utuh dengan troli yang sesuai standar ${ }^{5}$.

Perilaku penjamah makanan dalam menyajikan makanan perlu diperhatikan. Meskipun selalu menggunakan sarung tangan, alat untuk mengambil makanan tetap harus digunakan. Hal ini untuk menghindari kontaminasi makanan yang menyebabkan berubahnya cita rasa makanan. Manajemen rumah sakit perlu melakukan penyegaran kembali tentang higiene sanitasi pengelolaan makanan bagi penjamah makanan untuk meningkatkan kesadaran mereka. Hal ini perlu dilakukan untuk meningkatkan kualitas makanan ${ }^{17}$. Instrumen yang digunakan dalam penelitian ini belum divalidasi sehingga banyak hal yang terkait dengan penilaian higiene sanitasi pengelolaan makanan di rumah sakit luput dari pengamatan. Penyusunan instrumen penilaian ini selain melibatkan para ahli juga diuji validitasnya.

\section{SIMPULAN DAN SARAN}

Beberapa komponen dalam pengelolaan makanan di Rumah Sakit ABC Kabupaten Kubu Raya belum memenuhi penilaian yaitu komponen bebas gangguan serangga dan tikus, kondisi peralatan memasak, wadah penyimpanan makanan jadi, kualitas kereta pengangkut makanan (troli), dan perilaku penjamah makanan. Hal-hal tersebut perlu diperbaiki untuk menjamin keselamatan dan kesehatan pengguna. Selain itu, perlu dikembangkan instrumen penilaian higiene sanitasi pengelolaan makanan di rumah sakit sehingga dapat digunakan untuk menilai pelaksanaan pengelolaan makanan di rumah sakit.

\section{DAFTAR PUSTAKA}

1. Amaliyah N. Penyehatan Makanan dan Minuman-A. 01 ed. Yogyakarta: DEEPUBLISH; 2015. 
2. Rauf R. Sanitasi Pangan dan HACCP. 01 ed. Yogyakarta, editor. Graha Ilmu; 2013.

3. BPOM. Laporan Kinerja Badan POM. Jakarta; 2014.

4. Kemenkes RI. Peraturan Menteri Kesehatan Republik Indonesia Nomor 7 tahun 2019 tentang Kesehatan Lingkungan Rumah Sakit. 2019.

5. Kemenkes RI. Peraturan Menteri Kesehatan Republik Indonesia Nomor 56 Tahun 2014 tentang Klasifikasi dan Perizinan Rumah Sakit. 2014.

6. Kemenkes RI. Peraturan Menteri Kesehatan Republik Indonesia Nomor 1096/Menkes/Per/VI/2011 tentang Hygiene Jasaboga. 2011.

7. Kemenkes RI. Peraturan Menteri Kesehatan Republik Indonesia Nomor 78 Tahun 2013 tentang Pedoman Pelayanan Gizi Rumah Sakit. 2013.

8. Tamahaeng DA, Suwarja, Soenjono SJ, Kawatu YT. Keberadaan tikus, pinjal dan spesiesnya di RSUD Noongan Kabupaten Minahasa. JKL. 2016;6(1):1-5.

9. Prasetya RD, Yamtana, Amalia R. Pengaruh variasi warna lampu pada alat perekat lalat terhadap jumlah lalat rumah (Musca domestica) yang terperangkap. J BALABA. 2015;11(01):29-34.

10. Inayah A, Sukendra DM. Light trap dengan atraktan cuka hitam untuk mencegah transmisi penyakit tular vektor. Higeia J Public Heal Res Dev. 2019;3(4):513-23.

11. Ahmad I, Susanti S, Kustiati K, Yusmalinar S, Rahayu R, Hariani N. Resistensi lalat rumah, Musca domestica Linnaeus (Diptera: Muscidae) dari empat kota di Indonesia terhadap permetrin dan propoksur. J Entomol Indones. 2015;12(3):123-8.

12. Jiastuti T. Higiene sanitaskeberadaan bakteri pada makanan jadi di RSUD Dr Harjono Ponorogo. J Kesehat Lingkung. 2018;10(01):13-24.

13. Agustina T. Kontaminasi logam berat pada makanan dan dampaknya pada kesehatan. Teknobuga. 2014;1(1):53-65.

14. Thoha M, Lestyanto D, Widjasena B. Hubungan program HACCP dengan praktik keselamatan dan kesehatan kerja dan workplace hazard pada pekerja instalasi gizi di Rumah Sakit Islam Sultan Agung, Semarang. J Kesehat Masy. 2018;6(5):610-6.

15. Azizah SD, Rachmawati E. Analisis determinan kejadian nyaris cidera dan kejadian tidak diharapkan di Instalasi Gizi Rumah Sakit Anak dan Bunda Harapan Kita. Jukema. 2016;2(1):58-67.

16. Kadir S, Amalia S. Implementation of Hazard Analysis Critical Control Point Nutrition Service at Toto Kabila Regional Public Hospital, Bone Bolango. J Kesehat Masy. 2019;15(2):269-75.

17. Dermawan AK, Yanti DE, Amirus K. Analisis faktor yang berhubungan dengan ketidaksesuaian SOP petugas penjamah makanan di Instalasi Gizi Rumah Sakit Tipe C Kota Bandar Lampung tahun 2019. J Ilmu Kedokt dan Kesehat. 2020;7(1):326-33. 